\title{
The 2014 hot, dry summer in Northeast Asia
}

Article

Published Version

Wilcox, L., Dong, B., Sutton, R. and Highwood, E. (2015) The 2014 hot, dry summer in Northeast Asia. Bulletin of the American Meteorological Society, 96 (12). S105-S110. ISSN 1520-0477 doi: https://doi.org/10.1175/BAMS-D-15-00123.1 Available at https://centaur.reading.ac.uk/50985/

It is advisable to refer to the publisher's version if you intend to cite from the work. See Guidance on citing.

Published version at: https://www2.ametsoc.org/ams/index.cfm/publications/bulletin-of-the-american-meteorologicalsociety-bams/explaining-extreme-events-from-a-climate-perspective/toc/

To link to this article DOI: http://dx.doi.org/10.1175/BAMS-D-15-00123.1

Publisher: American Meteorological Society

All outputs in CentAUR are protected by Intellectual Property Rights law, including copyright law. Copyright and IPR is retained by the creators or other copyright holders. Terms and conditions for use of this material are defined in the End User Agreement.

www.reading.ac.uk/centaur

\section{CentAUR}

Central Archive at the University of Reading 
Reading's research outputs online 


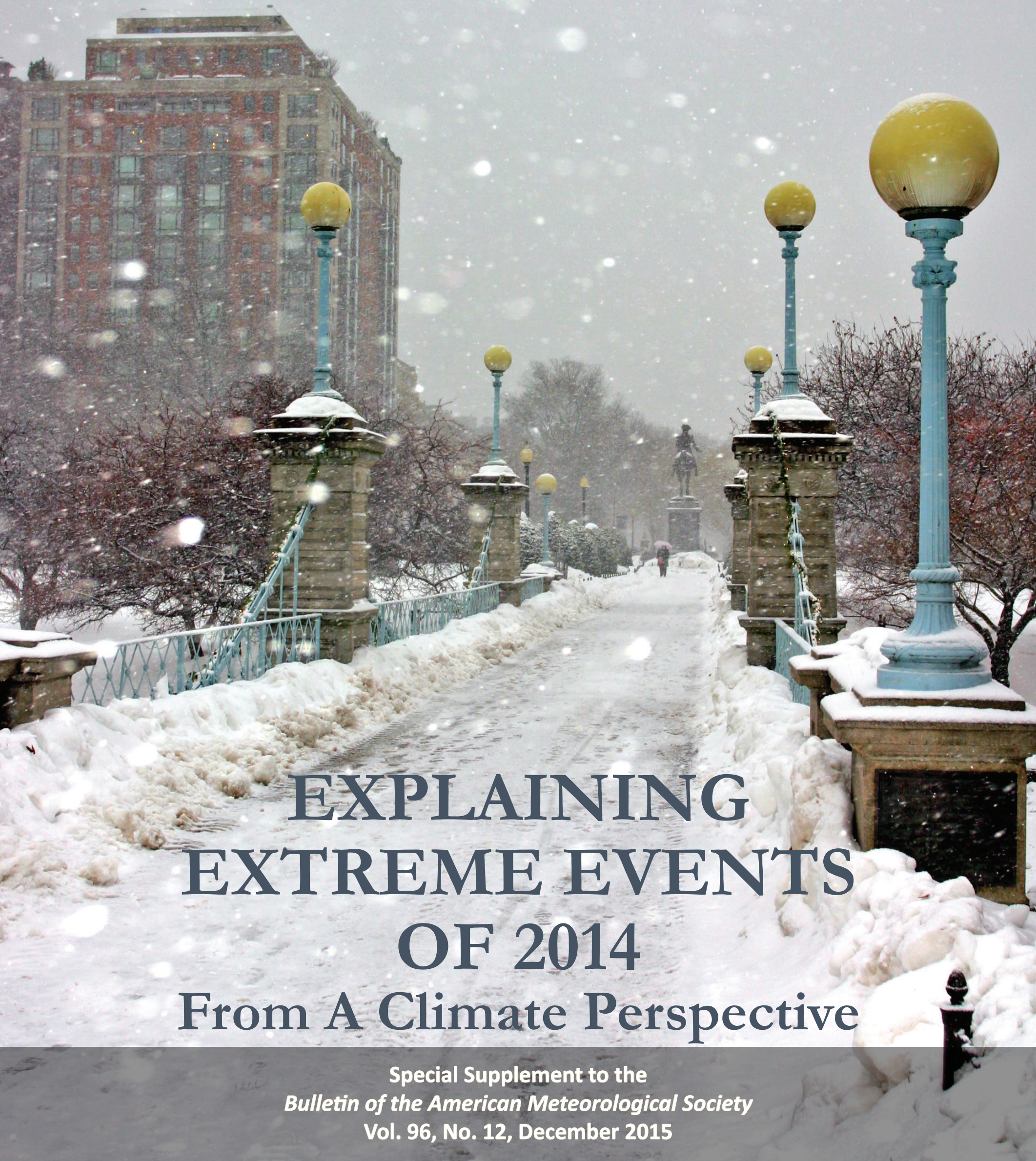




\section{EXPLAINING EXTREME EVENTS OF 20I4 FROM A CLIMATE PERSPECTIVE}

\section{Editors}

Stephanie C. Herring, Martin P. Hoerling, James P. Kossin, Thomas C. Peterson, and Peter A. Stott

Special Supplement to the

Bulletin of the American Meteorological Society

Vol. 96, No. I2, December 2015 
CORRESPONDING EDITOR:

Stephanie C. Herring, PhD

NOAA National Climatic Data Center

325 Broadway, E/CC23, Rm IB-I3I

Boulder, CO, 80305-3328

E-mail: stephanie.herring@noaa.gov

COVER CREDITS:

Front: (CiStockphotos.com/coleong-Winter snow, Boston Massachusetts, United States.

BACK: (CiStockphotos.com/nathanphoto-Legget, CA, United States - August I3 20I4: CAL FIRE helicopter surveys a part of the Lodge Fire, Mendocino County.

\section{HOW TO CITE THIS DOCUMENT}

Citing the complete report:

Herring, S. C., M. P. Hoerling, J. P. Kossin, T. C. Peterson, and P.A. Stott, Eds., 20I5: Explaining Extreme Events of 2014 from a Climate Perspective. Bull.Amer. Meteor. Soc., 96 (I2), SI-SI 72.

Citing a section (example):

Yoon, J. H., S.-Y. S. WANG, R. R. Gillies, L. Hipps, B. KravitZ, and P. J. Rasch, 20I5: Extreme fire season in California: A glimpse into the future? [in "Explaining Extremes of 2014 from a Climate Perspective"]. Bull. Amer. Meteor. Soc., 96 (I2), S5-S9.

\section{EDITORIAL AND PRODUCTION TEAM}

Riddle, Deborah B., Lead Graphics Production, NOAA/NESDIS National Centers for Environmental Information,

Asheville, NC

Love-Brotak, S. Elizabeth, Graphics Support, NOAA/NESDIS National Centers for Environmental Information,

Asheville, NC

Veasey, Sara W., Visual Communications Team Lead, NOAA/ NESDIS National Centers for Environmental Information, Asheville, NC

Griffin, Jessica, Graphics Support, Cooperative Institute for Climate and Satellites-NC, North Carolina State University, Asheville, NC

Maycock, Tom, Editorial Support, Cooperative Institute for Climate and Satellites-NC, North Carolina State University, Asheville, NC
Misch, Deborah J., Graphics Support, LMI Consulting, Inc., NOAA/NESDIS National Centers for Environmental Information, Asheville, NC

Osborne, Susan, Editorial Support, LMI Consulting, Inc., NOAA/NESDIS National Centers for Environmental Information, Asheville, NC

Schreck, Carl, Editorial Support, Cooperative Institute for Climate and Satellites-NC, North Carolina State University, and NOAA/NESDIS National Centers for Environmental Information, Asheville, NC

Sprain, Mara, Editorial Support, LAC Group, NOAA/NESDIS National Centers for Environmental Information, Asheville, NC

Young, Teresa, Graphics Support, STG, Inc., NOAA/NESDIS National Centers for Environmental Information, Asheville, NC 
Abstract.

I. Introduction to Explaining Extreme Events of 2014 from a Climate Perspective .................................

2. Extreme Fire Season in California: A Glimpse Into the Future? …………………..................................

3. How Unusual was the Cold Winter of 2013/14 in the Upper Midwest?............................................10

4. Was the Cold Eastern Us Winter of 2014 Due to Increased Variability? .............................................15

5. The 2014 Extreme Flood on the Southeastern Canadian Prairies .................................................... 20

6. Extreme North America Winter Storm Season of 2013/14: Roles of Radiative Forcing and the Global Warming Hiatus.......................................................................................................................... 25

7. Was the Extreme Storm Season in Winter 2013/14 Over the North Atlantic and the United Kingdom Triggered by Changes in the West Pacific Warm Pool?.

8. Factors Other Than Climate Change, Main Drivers of 2014/15 Water Shortage in Southeast Brazil..

9. Causal Influence of Anthropogenic Forcings on the Argentinian Heat Wave of December 2013

10. Extreme Rainfall in the United Kingdom During Winter 2013/14: The Role of Atmospheric Circulation and Climate Change.

II. Hurricane Gonzalo and its Extratropical Transition to a Strong European Storm.............................5I

12. Extreme Fall 2014 Precipitation in the Cévennes Mountains ........................................................ 56

13. Record Annual Mean Warmth Over Europe, the Northeast Pacific, and the Northwest Atlantic During 2014: Assessment of Anthropogenic Influence.

14. The Contribution of Human-Induced Climate Change to the Drought of 2014 in the Southern

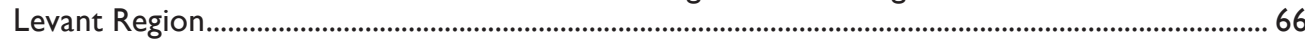

15. Drought in the Middle East and Central-Southwest Asia During Winter 2013/14............................ I

16. Assessing the Contributions of East African and West Pacific Warming to the 2014 Boreal Spring East African Drought

17. The 2014 Drought in the Horn of Africa: Attribution of Meteorological Drivers.

18. The Deadly Himalayan Snowstorm of October 2014: Synoptic Conditions and Associated Trends

19. Anthropogenic Influence on the 2014 Record-Hot Spring in Korea ................................................ 95

20. Human Contribution to the 2014 Record High Sea Surface Temperatures Over the Western Tropical And Northeast Pacific Ocean.

21. The 2014 Hot, Dry Summer in Northeast Asia .............................................................................. 105

22. Role of Anthropogenic Forcing in 2014 Hot Spring in Northern China........................................... III

23. Investigating the Influence of Anthropogenic Forcing and Natural Variability on the 2014 Hawaiian Hurricane Season.

24. Anomalous Tropical Cyclone Activity in the Western North Pacific in August 2014 .................. 120

25. The 2014 Record Dry Spell at Singapore: An Intertropical Convergence Zone (ITCZ) Drought.

26. Trends in High-Daily Precipitation Events in Jakarta and the Flooding of January 2014 ................131

27. Extreme Rainfall in Early July 2014 in Northland, New Zealand-Was There an Anthropogenic Influence?.

28. Increased Likelihood of Brisbane, Australia, G20 Heat Event Due to Anthropogenic Climate Change.

29. The Contribution of Anthropogenic Forcing to the Adelaide and Melbourne, Australia, Heat Waves of January 2014

30 Contributors to the Record High Temperatures Across Australia in Late Spring 2014 ............... 149

3I. Increased Risk of the 20I4 Australian May Heatwave Due to Anthropogenic Activity................ I54

32. Attribution of Exceptional Mean Sea Level Pressure Anomalies South of Australia in August 2014

33. The 2014 High Record of Antarctic Sea Ice Extent........................................................................ 163

34. Summary and Broader Context....................................................................................................... 168 


\section{ABSTRACT_Stephanie C. Herring, Martin P. Hoerling, James P. Kossin, Thomas C. Peterson, and Peter A. Stott}

Understanding how long-term global change affects the intensity and likelihood of extreme weather events is a frontier science challenge. This fourth edition of explaining extreme events of the previous year (2014) from a climate perspective is the most extensive yet with 33 different research groups exploring the causes of 29 different events that occurred in 2014. A number of this year's studies indicate that human-caused climate change greatly increased the likelihood and intensity for extreme heat waves in 2014 over various regions. For other types of extreme events, such as droughts, heavy rains, and winter storms, a climate change influence was found in some instances and not in others. This year's report also included many different types of extreme events. The tropical cyclones that impacted Hawaii were made more likely due to human-caused climate change. Climate change also decreased the Antarctic sea ice extent in 2014 and increased the strength and likelihood of high sea surface temperatures in both the Atlantic and Pacific Oceans. For western U.S. wildfires, no link to the individual events in 2014 could be detected, but the overall probability of western U.S. wildfires has increased due to human impacts on the climate.
Challenges that attribution assessments face include the often limited observational record and inability of models to reproduce some extreme events well. In general, when attribution assessments fail to find anthropogenic signals this alone does not prove anthropogenic climate change did not influence the event. The failure to find a human fingerprint could be due to insufficient data or poor models and not the absence of anthropogenic effects.

This year researchers also considered other humancaused drivers of extreme events beyond the usual radiative drivers. For example, flooding in the Canadian prairies was found to be more likely because of human land-use changes that affect drainage mechanisms. Similarly, the Jakarta floods may have been compounded by land-use change via urban development and associated land subsidence. These types of mechanical factors reemphasize the various pathways beyond climate change by which human activity can increase regional risk of extreme events. 


\title{
2I. THE 2014 HOT, DRY SUMMER IN NORTHEAST ASIA
}

\author{
L. J. WiLCOX, B. DONG, R. T. SUtTON, AND E. J. HIGHWOOD
}

Northeast Asia experienced a severe drought in summer 2014. Sea surface temperature forcing may have increased the risk of low precipitation, but model biases preclude reliable attribution to anthropogenic forcing.

Observational evidence. Northeast Asia (including a large part of north and northeast China, North Korea, and South Korea) experienced a severe drought in the summer (June to August, JJA) of 2014 (Fig. 21.1a). Seasonal mean rain rates were $1 \mathrm{~mm}^{\mathrm{m}} \mathrm{day}^{-1}$ less than the 1964-93 mean; a deficit of 30\%. It was the fourth driest year recorded by the Global Precipitation Climatology Centre (GPCC) since 1901 (after 1901, 1902, and 1943), and the third driest year recorded by the Global Precipitation Climatology Project (GPCP) since 1979 (after 1997 and 1999). The 2014 drought occurred in the context of over a decade of summer drought in the region, with an apparent phase shift in precipitation amounts taking place in the late 1990s (Fig. 21.1a). In addition to persistent summer droughts, northeast Asia has experienced steadily increasing temperatures in recent decades (Fig. 21.1b), and indeed most of Asia was warmer in JJA 2014 compared to the 1964-93 mean (Fig. 21.1c).

Summer drought in northeast Asia is part of a larger pattern of southern flooding and northern drought. This pattern is clear when JJA 2014 precipitation is compared to the 1964-93 mean (Fig. 21.1d). Comparing these anomalies to those relative to the more recent period since 1997 (Supplemental Fig. S21.1) shows that the summer of 2014 is an extreme example of the pattern of recent decades, and is therefore likely to be the result of similar underlying mechanisms.

The pattern of summer precipitation in east Asia is related to the meridional propagation of the Mei-Yu front. This is typically located over the south coast in May, propagates north to reach the Yangtze basin by June and northern China by July, and retreats in August with the end of the East Asian monsoon (e.g.,

\footnotetext{
AFFILIATIONS: WILCOX, Dong, AND SUTTON-National Centre for Atmospheric Science, Department of Meteorology, University of Reading, Reading, United Kingdom; HIGHWOOD-Department of Meteorology, University of Reading, Reading, United Kingdom

DOI:I0.II75/BAMS-D-15-00123.I

A supplement to this article is available online (10.1175 /BAMS-D-15-00123.2)
}

Chang et al. 2000). Drought occurs in northern China when the southerly flow over east China is weak, and the propagation of the Mei-Yu front stagnates in the Yangtze River valley (e.g., Zhu et al. 2011).

Summer drought in northern China has been observed to have significant quasi-50-year periodicity (Tan et al. 2014). The main factor controlling this decadal variability in precipitation is thought to be the southerly water vapor transport associated with the monsoon (e.g., Zhao et al. 2010; Tan et al. 2014). However, drought has also been attributed more widely to other factors, such as the positive phase of the Pacific decadal oscillation (PDO; e.g., Zhu et al. 2011), warming tropical Pacific and Indian Oceans (e.g., Zhao et al. 2010), anthropogenic aerosols (Xu 2001; Menon et al. 2002), and the positive phase of the Atlantic multidecadal oscillation (AMO; Qian et al. 2014).

The $850-\mathrm{hPa}$ wind anomalies for 2014 relative to 1964-93 (Fig. 21.1e), and to 1997 to 2014 (Supplemental Fig. S21.1f), show weakened southwesterly flow over China in 2014, consistent with slower northward propagation of the Mei-Yu front. They also show a weaker Indian monsoon circulation, which is again consistent with a more southerly location of the MeiYu front.

Sea surface temperature (SST) anomalies for 2014 relative to 1964-93 (Fig. 21.1f), and to 1997 to 2014 (Supplemental Fig. S21.1c), show very warm SSTs along the northern edge of the North Pacific and into the Bering Sea, extending along the western coast of North America. A tongue of cool SSTs extends from the south of Japan into the central North Pacific. Such anomalies are characteristic of the warm phase of the PDO, which has previously been associated with drought in northern China (e.g., Zhu et al. 2011). The similarity of the SST anomalies relative to 1964-93 and 1997 to 2014 suggest that 2014 is a particularly extreme case of the recent decadal pattern.

Indications from CMIP5. Historical experiments for the Coupled Model Intercomparison Project Phase 
(a)

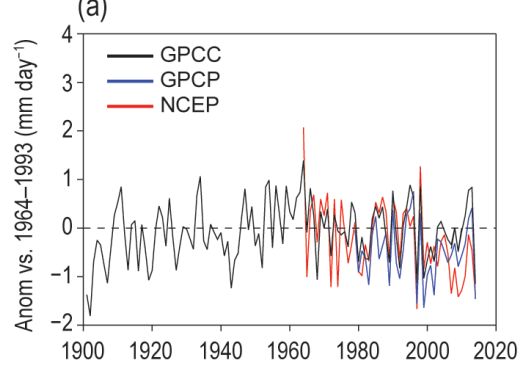

(d)

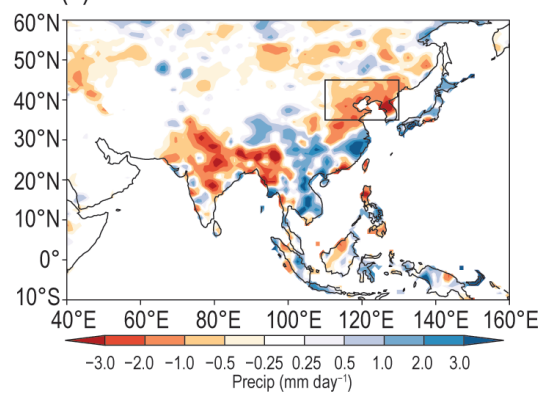

(b)

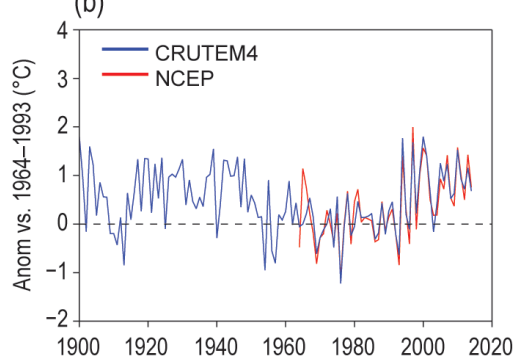

(e)

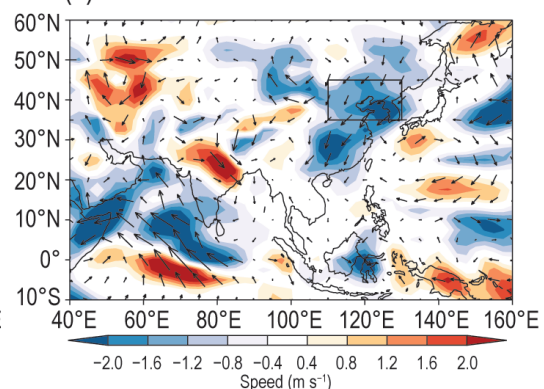

(c)

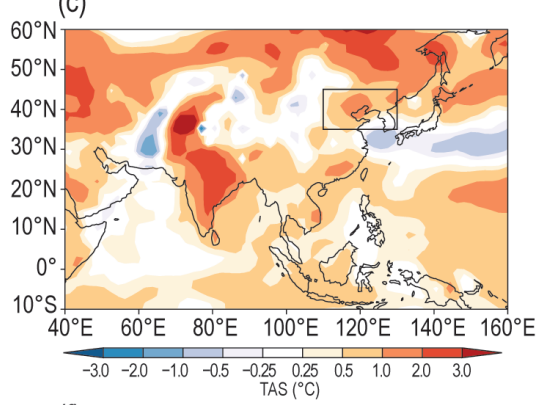

(f)

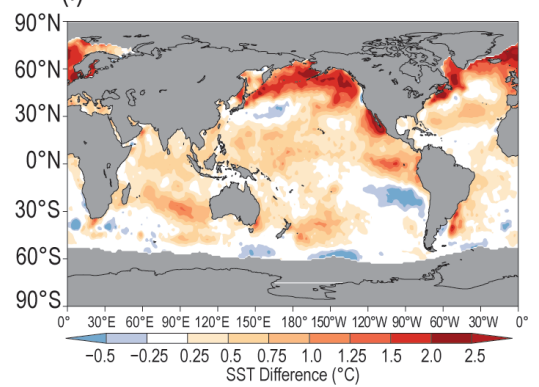

FIG. 2I.I. (a) Seasonal mean precipitation anomalies over northeast Asia from GPCC (Schneider et al. 20II, 2013), GPCP (Adler 2003), and the NCEP-NCAR reanalysis (Kalnay et al. 1996). The northeast Asia region is indicated by the boxes in panels (c)-(e). Anomalies are relative to 1964-93. GPCP is shown relative to the GPCC mean. (b) Seasonal mean temperature anomalies (relative to 1964-93) over northeast Asia from CRUTEM4 (Jones et al. 20I2) and the NCEP-NCAR reanalysis. (c) Near-surface temperature anomalies (2014 vs. 1964-93) from the NCEP-NCAR reanalysis. (d) Precipitation anomalies (2014 vs. 1964-93) from GPCC. (e) 850-hPa wind anomalies (20I4 vs. 1964-93) from NCEP-NCAR. (f) SST anomalies (20I4 vs. 1964-93) from HadISST.

5 (CMIP5) subset listed in Table 21.1 were compared for scenarios with all forcings, greenhouse gas (GHG) changes only, and anthropogenic aerosol (AA) changes only. The all-forcing simulations indicate a positive trend in multimodel mean JJA near-surface temperature in northeast Asia, in good agreement with HadCRUT4. This is driven primarily by GHG increases, mitigated in part by AA increases. However, the AA influence on temperature trends is small in recent decades (Supplemental Fig. 21.2).

The multi-model mean trend in precipitation in northeast Asia is small. GHG simulations show a small positive trend. AA forces a larger, bit still small, negative trend from around 1950 to around 1980, and little change in recent decades (Supplemental Fig. S21.2). CMIP5 mean precipitation does not show the

Table 2I.I. CMIP5 models, and the number of ensemble members for each experiment, used in this study.

\begin{tabular}{|l|c|c|c|c|l|}
\hline \multicolumn{1}{|c|}{ Center } & Model & $\begin{array}{c}\text { Historical } \\
\text { Members }\end{array}$ & $\begin{array}{c}\text { GHG-only } \\
\text { Members }\end{array}$ & $\begin{array}{c}\text { AA-only } \\
\text { Members }\end{array}$ & \multicolumn{1}{|c|}{ Reference } \\
\hline CCCma & CanESM2 & 5 & 5 & 5 & Von Salzen et al. (2013) \\
\hline $\begin{array}{l}\text { CSIRO- } \\
\text { QCCCE }\end{array}$ & CSIRO-Mk3.6.0 & 10 & 10 & 10 & Rotstayn et al. (2012) \\
\hline $\begin{array}{l}\text { NOAA- } \\
\text { GFDL }\end{array}$ & GFDL-CM3 & 3 & 3 & 2 & $\begin{array}{l}\text { Donner et al. (2011), } \\
\text { Levy et al. (2013) }\end{array}$ \\
\hline IPSL & IPSL-CM5A-LR & 6 & 3 & 1 & Dufresne et al. (2013) \\
\hline MOHC & HadGEM2-ES & 4 & 4 & 4 & $\begin{array}{l}\text { Bellouin et al. (2007), } \\
\text { Collins et al. (2011) }\end{array}$ \\
\hline NCC & NorESMI-M & 3 & 1 & 1 & Iversen et al. (2013) \\
\hline
\end{tabular}


pattern of decreases in the north and increases in the south seen in the NCEP-NCAR reanalysis. However, the consistent responses to forcing across the models suggests a degree of understanding of the forced response that is useful in quantifying the relative influence of AA and GHG on the sign and magnitude of the regional response.

Attribution using HadGEM3-A. We use the atmospheric component of the Hadley Centre Global Environment Model version 3 (HadGEM3-A; Hewitt et al. 2011), with prescribed SST and sea ice extent (SIE) from the Hadley Centre Sea Ice and Sea Surface Temperature dataset (HadISST; Rayner et al. 2003) to attempt to quantify the role of SST and SIE, GHG, and AA changes in causing the 2014 drought.

We use a set of four specially designed experiments for attribution of the 2014 drought (Table 21.2), analyzing the last 25 years of each 27-year experiment. Assuming responses to individual forcings can be linearly combined, we can examine the influence of each individual forcing component on the summer of 2014: GHG only (SSTGHG2014-SST2014), AA only (ALL2014-SSTGHG2014), SST only (SST2014CONTROL), and all-forcing (ALL2014-CONTROL).

The HadGEM3-A experiments show a reduction of precipitation over most of China, and in excess of $3 \mathrm{~mm}$ day $^{-1}$ in the south, in response to all forcings, associated with a weakening of the East Asian summer monsoon. SST changes account for the majority of the spatial structure and magnitude of the anomalies seen in the all-forcing case (Fig. 21.2). This is consistent with Zhu et al. (2011) who found that SST explained a large part of the weakening of the East Asian summer monsoon. AA and GHG changes cause an increase in precipitation (in HadGEM3-A) in northeast Asia (Fig. 21.2). This offsets the decrease in precipitation driven by SST changes, resulting in the small response seen in the all-forcing case.

Although AA and GHG appear only to make a small contribution to the HadGEM3-A all-forcing response compared to SST changes, this does not preclude an anthropogenic role in the severe drought of 2014. The HadGEM3-A response to SST may be exaggerated by a lack of air-sea coupling in the model (e.g., Zhu and Shukla 2013), and the SST changes themselves may have an anthropogenically driven component. In particular, drought in northern China has previously been linked to PDO and AMO variability, which are potentially driven, at least in part, by AA changes (Booth et al. 2012; Zhang et al. 2013; Allen et al. 2014; Boo et al. 2015).

The precipitation pattern in the mean of the 25 HadGEM3-A realizations of JJA 2014 does not agree with observations. Additionally, no single one of the 25 realizations correctly reproduces the precipitation pattern seen in observations (Supplemental Fig. S21.3). Thus no reliable attribution statement can be made. Christidis et al. (2013) found that HADGEM3A was unable to provide reliable results for the 2010 flooding in Pakistan, and suggested that biases in the Asian region may be the cause. All CMIP5 generation models have biases in this region, which need to be addressed for successful attribution (e.g., Sperber et al. 2013; Supplemental Fig. S21.2).

When forced with 1964-93 mean SST and SIE, HadGEM3-A has a zonal band of heavy precipitation over the Indian Ocean, a line of heavy precipitation

\begin{tabular}{|c|c|}
\hline Experiment & Boundary Conditions \\
\hline CONTROL & $\begin{array}{l}\text { Monthly climatological sea surface temperature (SST) and sea ice } \\
\text { extent (SIE) averaged over the period 1964-93, with greenhouse gas } \\
\text { (GHG) concentrations set at their mean values over the same period, } \\
\text { and anthropogenic aerosol (AA) precursor emissions (Lamarque et al. } \\
2010 \text { ) at mean values over the period 1970-93. }\end{array}$ \\
\hline ALL20I4 & $\begin{array}{l}\text { Forced with monthly mean SST and SIE from October } 2013 \text { to Sep- } \\
\text { tember } 2014 \text { using HadISST data, with GHG concentrations from } 2013 \\
\text { (WMO 20I4) and AA precursor emissions for } 2010 \text { (Lamarque et al. } \\
2010 \text { ), which is the most recent year for which emissions data were } \\
\text { available, and is not expected to be substantially different to actual } \\
2014 \text { emissions. }\end{array}$ \\
\hline $\begin{array}{l}\text { SST- } \\
\text { GHG20I4 }\end{array}$ & As ALL2014, but with AA precursor emissions the same as in CONTROL. \\
\hline SST2014 & $\begin{array}{l}\text { As ALL2014, but with GHG concentrations and AA precursor emissions } \\
\text { the same as in CONTROL. }\end{array}$ \\
\hline
\end{tabular}

following the Himalayas, and a line following the Burmese coast (Supplemental Fig. S21.4). Precipitation rates are too high over south China and too low over India in HadGEM3-A compared to the NCEP-NCAR reanalysis, which shows a more uniform precipitation distribution, with maxima off the Indian west coast and in the Bay of Bengal (Supplemental Fig. S21.4). The HadGEM3- 

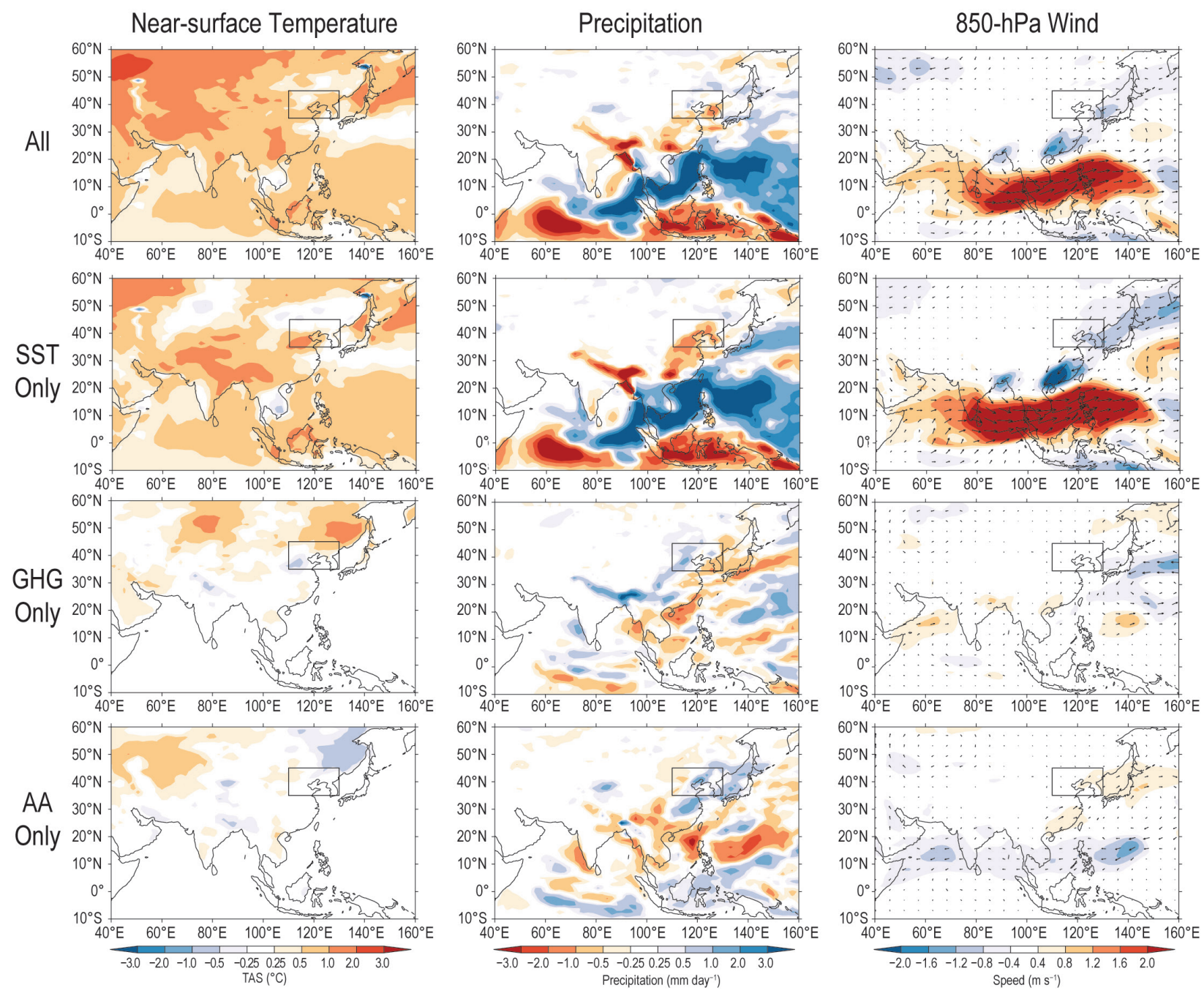

FIG. 21.2. HadGEM3-A responses to summer 2014 forcings, relative to the 1964-93 mean.

A Indian monsoon circulation is comparable to the reanalysis over the Arabian Sea, but weaker and more meridionally diffuse over India and the Bay of Bengal, with weaker flow into southern China. HadGEM3-A near-surface temperatures are generally too warm over Asia (Supplemental Fig. S21.4).

Conclusions. Northeast Asia experienced a severe drought in summer 2014. This was not an isolated event, occurring in the context of two decades of dry summers. The spatial pattern of precipitation in these years is for there to be flooding in southern China and drought in the north, linked to a stagnation of the northward propagation of the Mei-Yu front (e.g., Zhu et al. 2011).

Analysis of an ensemble of CMIP5 models suggests that it is likely that greenhouse gas emissions have caused increased summer temperatures in northeast Asia, partially offset by increasing anthropogenic aerosols. Precipitation responses to forcing are small. HadGEM3-A experiments designed to simulate summer 2014 show reductions in precipitation over China in response to recent changes in SST, but do not capture the observed pattern of precipitation anomalies, thus precluding definitive attribution.

Sperber et al. (2013) show that all climate models have biases in the Asian summer monsoon. Our results, and those of Christidis et al. (2013), suggest that these biases need to be reduced to enable successful attribution of extreme precipitation events in Asia.

ACKNOWLEDGEMENTS. This work was supported by the UK-China Research \& Innovation Partnership Fund through the Met Office Climate Science for Service Partnership (CSSP) China as part of the Newton Fund.

Data for the HadGEM2-ES anthropogenic aerosol only experiment was provided by Liang Guo. GPCC 
and GPCP precipitation data, and NCEP/NCAR reanalysis data were provided by the NOAA/OAR/ESRL PSD, Boulder, Colorado, via their website at www.esrl .noaa.gov/psd/. CRUTEM4.3 temperature data was provided by CRU, via their website at www.cru.uea .ac.uk/cru/data/temperature/. HadISST temperature data was provided by the UK Met Office, via their website at www.metoffice.gov.uk/hadobs/hadisst /data/download.html.

We acknowledge the World Climate Research Programme's Working Group on Coupled Modelling, which is responsible for CMIP, and we thank the climate modelling groups for producing and making available the model output listed in Table 21.1. For CMIP the U.S. Department of Energy's Program for Climate Model Diagnosis and Intercomparison provides coordinating support and led development of software infrastructure in partnership with the Global Organization for Earth System Science Portals. We also thank the British Atmospheric Data Centre (BADC) for providing access to their CMIP5 data archive.

\section{REFERENCES}

Adler, R. F., and Coauthors, 2003: The version 2 Global Precipitation Climatology Project (GPCP) monthly precipitation analysis (1979-Present). J. Hydrometeor., 4, 1147-1167.

Allen, R. J., J. R. Norris, and M. Kovilakam, 2014: Influence of anthropogenic aerosols and the Pacific decadal oscillation on tropical belt width. Nat. Geosci., 7, 270-274, doi:10.1038/ngeo2091.

Bellouin, N., O. Boucher, J. Haywood, C. Johnson, A. Jones, J. Rae, and S. Woodward, 2007: Improved representation of aerosols for HadGEM2. Hadley Centre Tech. Note 73, $42 \mathrm{pp}$. [Available online at www.metoffice.gov.uk/media/pdf/8/f/HCTN_73 .pdf.]

Boo, K.-O., B. B. B. Booth, Y.-H. Byun, J. Lee, C. H. Cho, S. Shim, and K.-T. Kim, 2015: Influence of aerosols in multidecadal SST variability simulations over the North Pacific. J. Geophys. Res. Atmos., 120, 517-531, doi:10.1002/2014JD021933.

Booth, B. B. B., N. J. Dunstone, P. R. Halloran, T. Andrews, and N. Bellouin, 2012: Aerosols implicated as a prime driver of twentieth-century North Atlantic climate variability. Nature, 484, 228-232.

Chang, C., Y. Zhang, and T. Li, 2000: Interannual and interdecadal variations of the East Asian summer monsoon and tropical Pacific SSTs. Part I: Roles of the subtropical ridge. J. Climate, 13, 4310-4325.
Christidis, N., P. A. Stott, A. A. Scaife, A. Arribas, G. S. Jones, D. Copsey, J. R. Knight, and W. J. Tennant, 2013: A new HadGEM3-A-based system for attribution of weather- and climate-related extreme events. J. Climate, 26, 2756-2783, doi:10.1175 /JCLI-D-12-00169.1.

Collins, W., and Coauthors, 2011:Developmentand evaluation of an Earth-system model - HadGEM2. Geosci. Model Dev., 4, 1051-1075, doi:10.5194/gmd-4-1051 -2011 .

Donner, L., and Coauthors, 2011: The dynamical core, physical parameterizations, and basic simulation characteristics of the atmospheric component AM3 of the GFDL global coupled model CM3. J. Climate, 24, 3484-3519, doi:10.1175/2011JCLI3955.1.

Dufresne, J.-L., and Coauthors, 2013: Climate change projections using the IPSL-CM5 Earth System Model: From CMIP3 to CMIP5. Climate Dyn., 40, 2123-2165, doi:10.1007/s00382-012-1636-1.

Hewitt, H. T., D. Copsey, I. D. Culverwell, C. M. Harris, R. S. R. Hill, A. B. Keen, A. J. McLaren, and E. C. Hunke, 2011: Design and implementation of the infrastructure of HadGEM3: The next-generation Met Office climate modelling system. Geosci. Model Dev., 4, 223-253, doi:10.5194/gmd-4-223-2011.

Iversen, T., and Coauthors, 2013: The Norwegian Earth System Model, NorESM1-M - Part 2: Climate response and scenario projections. Geosci. Model Dev., 6, 389-415, doi:10.5194/gmd-6-389-2013.

Jones, P. D., D. H. Lister, T. J. Osborn, C. Harpham, M. Salmon, and C. P. Morice, 2012: Hemispheric and large-scale land surface air temperature variations: An extensive revision and an update to 2010. J. Geophys. Res., 117, D05127, doi:10.1029/2011JD017139.

Kalnay, E., and Coauthors, 1996: The NCEP/NCAR 40year reanalysis project. Bull. Amer. Meteor. Soc., 77, 437-470.

Lamarque, J.-F., and Coauthors, 2010: Historical (1850-2000) gridded anthropogenic and biomass burning emissions of reactive gases and aerosols: Methodology and application. Atmos. Chem. Phys., 10, 7017-7039, doi:10.5194/acp-10-7017-2010.

Levy, H., L. W. Horowitz, M. D. Schwarzkopf, Y. Ming, J.-C. Golaz, V. Naik, and V. Ramaswamy, 2013: The roles of aerosol direct and indirect effects in past and future climate change. J. Geophys. Res. Atmos., 118, 4521-4532, doi:10.1002/jgrd.50192.

Menon, S., J. Hansen, L. Nazarenko, and Y. Luo, 2002: Climate effects of black carbon aerosols in China and India. Science, 297, 2250-2253. 
Qian, C., J.-Y. Yu, and G. Chen, 2014: Decadal summer drought frequency in China: The increasing influence of the Atlantic Multi-decadal Oscillation. Environ. Res. Lett., 9, 124004, doi:10.1088/1748 $-9326 / 9 / 12 / 124004$.

Rayner, N. A., D. E. Parker, E. B. Horton, C. K. Folland, L. V. Alexander, D. P. Rowell, E. C. Kent, and A. Kaplan, 2003: Global analyses of sea surface temperature, sea ice, and night marine air temperature since the late nineteenth century. J. Geophys. Res., 108, 4407, doi:10.1029/2002JD002670.

Rotstayn, L., S. Jeffrey, M. Collier, S. Dravitzki, A. Hirst, J. Syktus, and K. Wong, 2012: Aerosol- and greenhouse gas-induced changes in summer rainfall and circulation in the Australasian region: A study using single-forcing climate simulations. Atmos. Chem. Phys., 12, 6377-6404, doi:10.5194/acp-12-6377-2012. Schneider, U., A. Becker, P. Finger, A. Meyer-Christoffer, B. Rudolf, and M. Ziese, 2011: GPCC full data reanalysis version 6.0 at 1.0 degree: Monthly landsurface precipitation from rain-gauges built on GTSbased and historic data. Deutscher, Wetterdienst, Offenbach, Germany, digital media, doi:10.5676 /DWD_GPCC/FD_M_V6_100.

,,,---- , M. Ziese, and B. Rudolf, 2013: GPCC's new land surface precipitation climatology based on quality-controlled in situ data and its role in quantifying the global water cycle. Theor. Appl. Climatol., 115, 15-40, doi:10.1007/s00704-013 -0860-x.

Sperber, K. R., H. Annamalai, I.-S. Kang, A. Kitoh, A. Moise, A. Turner, B. Wang, and T. Zhou, 2013: The Asian summer monsoon: An intercomparison of CMIP5 vs. CMIP3 simulations of the late 20th century. Climate Dyn., 41, 2711-2744, doi:10.1007 /s00382-012-1607-6.

Tan, L., and Coauthors, 2014: Cyclic precipitation variation on the western Loess Plateau of China during the past four centuries. Sci. Rep., 4, 6381, doi:10.1038 /srep06381.

von Salzen, K., and Coauthors, 2013: The Canadian fourth generation atmospheric global climate model (CanAM4). Part I: Representation of physical processes. Atmos.-Ocean, 51, 104-125, doi:10.1080 /07055900.2012.755610.

WMO, 2014: The state of greenhouse gases in the atmosphere based on global observations through 2013 WMO Greenhouse Gas Bulletin, No. 10, 8 pp. [Available online at www.wmo.int/pages/prog/arep/gaw /ghg/GHGbulletin.html.]
Xu, Q., 2001: Abrupt change of the mid-summer climate in central east China by the influence of atmospheric pollution. Atmos. Environ., 35, 5029-5040.

Zhang, R., and Coauthors, 2013: Have aerosols caused the observed Atlantic multidecadal variability? J. Atmos. Sci., 70, 1135-1144, doi:10.1175/JAS -D-12-0331.1.

Zhao, P., S. Yang, and R. Yu, 2010: Long-term changes in rainfall over eastern china and largescale atmospheric circulation associated with recent global warming. J. Climate, 23, 1544-1562, doi:10.1175/2009JCLI2660.1.

Zhu, J., and J. Shukla, 2013: The role of air-sea coupling in seasonal prediction of Asia-Pacific summer monsoon rainfall. J. Climate, 26, 5689-5697, doi:10.1175 /JCLI-D-13-00190.1.

Zhu, Y., H. Wang, W. Zhou, and J. Ma, 2011: Recent changes in the summer precipitation pattern in East China and the background circulation. Climate Dyn., 36, 1463-1473, doi:10.1007/s00382 -010-0852-9. 


\begin{tabular}{|c|c|c|c|}
\hline \multicolumn{4}{|c|}{ ON EVENT STRENGTH † } \\
\hline & INCREASE & DECREASE & NOT FOUND OR UNCERTAIN \\
\hline Heat & $\begin{array}{l}\text { Australia (Ch. 31) } \\
\text { Europe (Ch.13) } \\
\text { S. Korea (Ch. 19) }\end{array}$ & & $\begin{array}{l}\text { Australia, Adelaide \& Melbourne } \\
\text { (Ch. 29) } \\
\text { Australia, Brisbane (Ch.28) }\end{array}$ \\
\hline Cold & & Upper Midwest (Ch.3) & \\
\hline $\begin{array}{l}\text { Winter } \\
\text { Storms and } \\
\text { Snow }\end{array}$ & & & $\begin{array}{l}\text { Eastern U.S. (Ch. 4) } \\
\text { N. America (Ch. 6) } \\
\text { N. Atlantic (Ch. 7) }\end{array}$ \\
\hline $\begin{array}{c}\text { Heavy } \\
\text { Precipitation }\end{array}$ & Canada** (Ch. 5) & & $\begin{array}{l}\text { Jakarta***** (Ch. 26) } \\
\text { United Kingdom } * * * *(C h .10) \\
\text { New Zealand (Ch. 27) }\end{array}$ \\
\hline Drought & $\begin{array}{l}\text { E. Africa (Ch. 16) } \\
\text { E. Africa* (Ch. 17) } \\
\text { S. Levant (Ch. 14) }\end{array}$ & & $\begin{array}{l}\text { Middle East and S.W. Asia } \\
(\text { Ch. 15) } \\
\text { N.E. Asia (Ch. 2I) } \\
\text { Singapore (Ch. 25) }\end{array}$ \\
\hline $\begin{array}{l}\text { Tropical } \\
\text { Cyclones }\end{array}$ & & & $\begin{array}{l}\text { Gonzalo (Ch. II) } \\
\text { W. Pacific (Ch. 24) }\end{array}$ \\
\hline Wildfires & & & California (Ch. 2) \\
\hline $\begin{array}{l}\text { Sea Surface } \\
\text { Temperature }\end{array}$ & $\begin{array}{l}\text { W. Tropical \& N.E. Pacific (Ch. 20) } \\
\text { N.W. Atlantic \& N.E. Pacific (Ch. 13) }\end{array}$ & & \\
\hline $\begin{array}{l}\text { Sea Level } \\
\text { Pressure }\end{array}$ & S. Australia (Ch. 32) & & \\
\hline $\begin{array}{l}\text { Sea Ice } \\
\text { Extent }\end{array}$ & & & Antarctica (Ch. 33) \\
\hline
\end{tabular}

$\dagger$ Papers that did not investigate strength are not listed.

t† Papers that did not investigate likelihood are not listed.

* No influence on the likelihood of low rainfall, but human influences did result in higher temperatures and increased net incoming radiation at the surface over the region most affected by the drought.

** An increase in spring rainfall as well as extensive artificial pond drainage increased the risk of more frequent severe floods from the enhanced rainfall.

*** Evidence for human influence was found for greater risk of UK extreme rainfall during winter 2013/14 with time scales of 10 days

***** The study of Jakarta rainfall event of 2014 found a statistically significant increase in the probability of such rains over the last 115 years, though the study did not establish a cause. 


\title{
ON EVENT LIKELIHOOD ††
}

Argentina (Ch. 9)

Australia (Ch. 30, Ch. 3I)

Australia, Adelaide (Ch. 29)

Australia, Brisbane (Ch. 28)

Melbourne, Australia (Ch. 29)

Europe (Ch. 13)

S. Korea (Ch. 19)

China (Ch. 22)

Cold
Winter
Storms and
Snow

Heavy
Precipitation

(a)

N. America (Ch. 6)

S. France (Ch. I2)

Middle East and S.W. Asia (Ch. 15)

Drought

E. Africa (Ch. 16)

S. Levant (Ch. 14)

E. Africa* (Ch. 17)

N.E. Asia (Ch. 2I)

Wildfires

\author{
California (Ch. 2)
}

\section{W. Tropical \& N.E. Pacific}

Sea Surface

Temperature

(Ch. 20)

N.W. Atlantic \& N.E. Pacific (Ch. 13)

Sea Level

Pressure

S. Australia (Ch. 32)

Sea Ice

Extent

w.

Antarctica (Ch. 33)

† Papers that did not investigate strength are not listed.

t† Papers that did not investigate likelihood are not listed.

* No influence on the likelihood of low rainfall, but human influences did result in higher temperatures and increased net incoming radiation at the surface over the region most affected by the drought.

** An increase in spring rainfall as well as extensive artificial pond drainage increased the risk of more frequent severe floods from the enhanced rainfall.

*** Evidence for human influence was found for greater risk of UK extreme rainfall during winter 2013/14 with time scales of 10 days

***** The study of Jakarta rainfall event of 2014 found a statistically significant increase in the probability of such rains over the last II5 years, though the study did not establish a cause. 